\title{
Fair and Equitable Treatment Standard in International Investment Law: The Customary Status
}

\author{
Mujeeb Rahman Emami \\ School of law Zhongnan University of Economics and Law, 430073 Wuhan, China \\ Email: mujeebemami@gmail.com, Tel: +8613125195352
}

\begin{abstract}
Fair and equitable treatment (FET) is an important standard in international investment law. However, this standard is not free of controversy among governments, scholars and in arbitral tribunals. The historical challenge of FET is its relation with international minimum standard of treatment under customary international law. In recent times, a new challenge arose asking whether FET itself has entered into the family of customary international law or not. This inquiry is important because if the standard has, in fact, become a part of customary international law, then even where States exclude reference to FET for foreign investors in their treaty arrangements, this level of treatment will come into effect by operation of law to such investors. This paper seeks to find an answer for this question. In this respect, the paper first went through the opinions of different scholars. As observed, a few of them supported such a recognition by basing their ideas mostly on the inclusion of FET in the majority of for instance BITs. While the rest of scholars has opposed such an idea by backing the conventional status of FET or pointing on the lack of uniformity of State practice plus the absence of opinio juris among countries. In the second step, the paper analyzed the arbitral cases dealing with such a question. It found, that except a few cases, the rest have not agreed to such a recognition. Finally, the paper looked for the requirement of State practice and opinio juris to see if FET has become part of customary international law. It found that although State practice is general and representative but it is not uniform and consistent. In addition, there was no opinio juris or legally binding believe to accept the customary status of FET. In short, the majority of scholars, arbitral practice, as well as the practice of state and opinio juris does not confirm that FET has entered into the corpus of customary international law.
\end{abstract}

Keywords: Fair and Equitable Treatment, Customary International Law, Multilateral Agreements, BITs, Arbitral Practice, State Practice

DOI: $10.7176 / \mathrm{JLPG} / 105-14$

Publication date: January $31^{\text {st }} 2021$

\section{Introduction}

The Fair and equitable standard (FET) has become one of the most important standards which provides protection through international investment instruments and is regularly invoked by the foreign investors as a basis for requiring compensation from host States. Unlike other standards, it is a non-contingent standard, which is so broad and vague. In addition, it is a unilateral obligation of host States. The first appearance of the standard was in Havana Charter of $1948^{1}$ as a desirable basis for the treatment of investment in foreign countries. The broad usage of FET for the protection of foreign investors came through the network of bilateral investment treaties (BITs) from 1960's onwards. However, the FET standard became one of the most controversial issues in the international investment law since 1997 when the AMT tribunal ${ }^{2}$ discussed the violation by a State of its FET obligation for the first time. Later on, the relationship of FET with minimum standard of treatment has been the most controversial one. Here, the main question has been whether FET is part of MST or is it with a reference to MST under customary international law or not. The answer to this question is not the focus of this paper.

However, now, there is a theoretical question that whether FET itself has become a rule of customary international law or not. This inquiry is important because if the standard has, in fact, become a part of customary international law, then even where States exclude reference to FET for foreign investors in their treaty arrangements, this level of treatment will come into effect by operation of law to such investors. ${ }^{3}$ While if it has not become, the courts would not be able to bring it into play unless it was formally contained in investment treaties. Some commentators have supported the argument of FET as a rule of custom. For example, Schwebel

\footnotetext{
${ }^{1}$ Havana Charter for the Establishment of an International Trade Organization ('Havana Charter') (signed 24 March 1948).

${ }^{2}$ American Manufacturing \& Trading, Inc. v Democratic Republic of Congo (AMT case), ICSID Case No.ARB/93/1, Award, 21 February 1997.

${ }^{3}$ Deng, Tingting. "The impact of the fair and equitable treatment standard on state sovereignty: from the perspective of international investment practice." PhD diss., City University of Hong Kong, 2012, p. 68.
} 
asserted that FET embodied in treaties is received by now in customary international law. ${ }^{1}$ Similarly, FA Mann claims that just because the relevant standard is embodied in the treaty, it replaces customary norms on the same subject. ${ }^{2}$ However, Vasciannie is in favor of the view that FET has not passed into the body of customary law due to the lack of consistency of practice as well as opinio juris. ${ }^{3}$ In addition, Dumberry in his findings proves that while the States possess a general, widespread and representative practice, nevertheless it is not uniform and consistent enough for the standard to have entered into a customary rule let alone the lack of opinio juris. ${ }^{4}$

This paper aims to answer the question over the customary status of FET. Therefore, in the second section, this paper will go through different conflicting arguments supporting or opposing such a recognition. In the third section, the arbitral cases dealing with such a question will be analyzed and in the last section, the States' practice and their opinio juris will be searched for to find out if the standard has entered into customary international law. Subsequently, a conclusion will be followed.

\section{The Various Arguments over FET as a Rule of Custom}

The main arguments for this transformation is the inclusion of FET in multilateral treaties as well as in the overwhelming majority of BITs. First, in the context of multilateral instruments, the basic rule established by the ICJ in the North Sea Continental shelf is of relevance. In this case, the ICJ laid one important criteria that the standard is of a 'fundamentally norm-creating character and there has been time enough for the rule to assume customary status. ${ }^{5}$ This criterion does not seem to be satisfied with regard to FET particularly in relation to majority of multilateral instruments. For example, the international instruments containing FET such as Havana Charter ${ }^{6}$, the Abs-Shawcross Draft ${ }^{7}$, and the OECD Draft ${ }^{8}$, all failed to achieve the treaty status. Thus, it can be argued that this failure of lacking enough state support to enter into force as treaties indicates the weak norm creating possibility for these instruments. ${ }^{9}$ That is not to say, that some provisions within them may reflect the customary international law. The truth is that the customary status of those provisions represents State practice and opinio juris with or without those unratified instruments. ${ }^{10}$

The North Sea criteria is contrasted with the relaxed approach to the identification of customary norms in Fisheries Jurisdiction cases (Merits). ${ }^{11}$ In this case, the ICJ seemed content to admit that a resolution and a proposal backed by large majorities at the First and Second United Nations Conferences on the Law of the Sea, correspondingly, indicated overwhelming support for a particular rule in customary law. ${ }^{12}$ However, it seems that even if this method is accepted, the failed instruments mentioned above still looks deficient. ${ }^{13}$ To take the example of the Havana Charter, the purpose of the charter was not to create a binding treaty obligation on FET, as it would be idiosyncratic to do so. ${ }^{14}$ In the meantime, the Abs-Shawcross Draft in itself was not able to produce a customary rule on FET, as it also did not receive a formal support from States. ${ }^{15}$ As for the OECD Draft, there is a point that FET could have developed as a rule CIL because of some degree of State scrutiny over the draft. This can be counter argued with three reasons. First, the OECD Draft seems to have represented only the developed countries not the developed ones as they lack express support for such a recognition. Second a lack of opinio juris among a great number of States confirming the OECD document as enshrining the standard in customary law. Third, this

\footnotetext{
${ }^{1}$ Schwebel, The Influence of Bilateral Investment Treaties on Customary International Law. 98 ASIL Proceedings (2004), 27.

${ }^{2}$ FA Mann, British Treaties for the Promotion and Protection of Investments, 5 BYIL (1982), 249.

${ }^{3}$ S. Vasciannie, 'The Fair and Equitable Treatment Standard in International Investment Law and Practice', BYIL 70 (1999), 160-161,164

${ }^{4}$ Dumberry P (2017) Fair and Equitable Treatment: Its Interaction with the Minimum Standard and its Customary Status (Brill Research Perspectives in International Investment Law and Arbitration), pp.49-50.

${ }^{5}$ North Sea Continental Shelf Cases (Federal Republic of Germany v. Denmark / Federal Republic of Germany v. Netherlands), [1969] ICJ Rep 42, [72]; on this issue see also Mark E. Villiger, Customary International law and Treaties: A Manual on the Theory and Practice of the Interrelation of Sources (2nd edn., Kluwer 1997), pp. 177-178.

${ }^{6}$ International Trade Organization, The Havana Charter (1948)

${ }^{7}$ The Abs-Shawcross Draft Convention on Investment Abroad (1957)

${ }^{8}$ OECD, Draft Convention on the Protection of Foreign Property (1967)

${ }^{9}$ See Vasciannie (above fn 6), p. 155

${ }^{10}$ Ibid., at p. 154; on the possibility that some provisions in a multilateral treaty may have customary status while others do not, see also, for example, the North Sea Continental Shelf cases, at p. 39, para. 63.

${ }^{11}$ Fisheries Jurisdiction case (UK V. Iceland) (Merits), ICJ Reports, 1974, p. 3

${ }^{12}$ Ibid. p. 26, para. 58

${ }^{13}$ See Vasciannie (above fn 6) p. 155

${ }^{14}$ Ibid. at pp. 108, 155; See also UNCTAD, International Investment Instruments: A Compendium (1996), vol. I, p. xx.

${ }^{15}$ Ibid at p. 155
} 
draft, with the passage of time, did not evolve from the status of a draft to that of a binding treaty making it difficult although not impossible to argue that, the FET in OECD text is a part of CIL. ${ }^{1}$

Similarly, these arguments also involve with regard to the more recent instruments such as the World Bank Guidelines, ${ }^{2}$ the NAFTA Agreement ${ }^{3}$ and the Multilateral Agreement on Investment. ${ }^{4}$ These agreements though demonstrating some degree of political acceptance of the standard do not reflect broad consensus particularly among developing countries over the customary status of FET as a rule of custom. ${ }^{5}$ To begin with, the World Bank Guidelines issued in 1992, it did not meant to be declaratory of customary law on the standard of treatment for foreign investors. ${ }^{6}$ This is reflected in the World Bank Development committee notes explaining that it is reports on the Guidelines "does not aim at representing a codification of what are necessarily agreed upon, binding rules of international law. Rather it attempts to reflect at this stage generally acceptable international standards which meet the objective stated in the Development Committee's request, i.e., the promotion of foreign direct investment". 7 As for the other two instruments, NAFTA has a limited membership and lack a widespread cross-sectional support to claim that FET has entered into customary law. Similarly, Multilateral Agreement on Investment also faced with the lack of cross-sectional accord in addition to the fact that it was not able to gather support even from capital exporting countries involved in negotiating its term. ${ }^{8}$

Departing from multilateral instruments, this issue is more debatable with respect to BITs. First, the supportive argument here is that when a rule is repeated in a number of BITs, this in itself indicate an evidence that the rule has become a part of customary law. ${ }^{9}$ Likewise, the inclusion of FET in the vast majority of BITs could lead to the claim that States, irrespective of the treaty obligation, accept the standard as legally binding. Therefore, only the significant similarity of the approach displayed in a vast number of BITs would provide the two requirements of State practice and opinio juris in support of the rule in customary law. ${ }^{10}$ As, Tudor posits 'the FET standard became a customary norm of its time; quick in its formation and based essentially on a State practice derived from the treaties signed by an overwhelming number of States, which in the majority contain an FET clause. She moreover suggests that FET should be envisaged as a form of 'coutume sauvage, made from a network of uniform BITs, an argument to cover the lack of opinio juris. ${ }^{11}$ In other words, this implies that FET is a customary rule in its own right. Here, it cast doubt on the capability of MST for being too slow to meet the current international law challenges. One further robust support is the Diehl's argument who states that not only FET as such has evolved into a customary rule (parallel and distinct from MST), but furthermore that it 'ought to be recognized as a general principle of law'. ${ }^{12}$ In addition, given that the impact of the standard is further extended by invoking the most-favoured nation standard, this claim possesses a solid factual foundation. ${ }^{13}$

However, there are several counter arguments to deny the customary status of FET. The first counter argument goes the opposite conclusion of the above argument highlighting the inclusion of FET in majority of BITs. In fact, as Weiler describes this inclusion of FET in BITs by States in a consistent manner can also mean that no such standard of protection exist under custom. ${ }^{14}$ This takes us to conclude that if FET exited under custom, States would not need to include such protection in their BITs. Thereby, the mere existence of FET even with its

\footnotetext{
${ }^{1}$ Ibid. pp. 155-156

${ }^{2}$ World Bank Guidelines on the Treatment of Foreign Direct Investment ('World Bank Guidelines 1992).

${ }^{3}$ North American Free Trade Agreement ('NAFTA') (signed 17 December 1992, entered into force 1 January 1994).

${ }^{4}$ OECD Multilateral Agreement on Investment ('MAI') (draft-consolidated text of 22 April 1998).

${ }^{55}$ See Vasciannie (above fn 6) p. 156

${ }^{6}$ Ibid.

${ }^{7}$ Rubin, Introductory Note on 'World Bank: Report to the Development Committee and Guidelines on the Treatment of Foreign Direct Investment', International Legal Materials, 3 I (1992), p. 1369

${ }^{8}$ See Vasciannie (above fn 6) p. 156

${ }^{9}$ Ioana Tudor, The Fair and Equitable Treatment Standard in International Foreign Investment Law (Oxford UP 2008), pp. $65-$ 68; Alexandra Diehl, The Core Standard of International Investment Protection: Fair and Equitable Treatment (Wolters Kluwer 2012), pp. 10-11, 125-153, 175-179; Alfred Siwy, 'Investment Arbitration - Indirect Expropriation and the Legitimate Expectations of the Investor' in Christian Klausegger et al. (eds), Austrian Arbitration Yearbook 2007 (C.H. Beck, Stämpfli and Manz 2007); Courtney C. Kirkman, 'Fair and Equitable Treatment: Methanex v. United States and the Narrowing Scope of NAFTA Article 1105', (2002-2003) 34 Law \& Pol'y Int'l Bus., p. 392; Todd Weiler, 'NAFTA Investment Arbitration and the Growth of International Economic Law', (2002) 2 Bus. L. Int'1, p. 188; I. Laird, 'Betrayal, Shock and Outrage - Recent Developments in NAFTA Article 1105', in T. Weiler (ed.), NAFTA Investment Law and Arbitration: Past Issues, Current Practice, Future Prospects (Transnational Publ., 2004) pp. 70-74.

${ }^{10}$ Vasciannie (n 6) p. 157

${ }^{11}$ Tudor (n 27) p. 85

${ }^{12}$ Diehl (n27) pp. $124-179$.

${ }^{13}$ Vasciannie (n 6) p. 157

${ }^{14}$ Weiler (n 27) p. 236
} 
impressive number does not confer the FET a customary status. ${ }^{1}$ In this point, the ICJ rule is clear as it notes that 'the frequency or even habitual character of the acts is not in itself enough, States must feel that they are conforming to what amounts to a legal obligation'. ${ }^{2}$ Therefore, it is obvious that rules of CIL develop over time based on the uniform and consistent practice of a large number of representative States, which have the conviction or believe that such practice is required by law meaning the opinio juris.

The second counter argument takes a historical ride to the development of FET in the context of BITs. Here, the opposed argument to FET as a rule of custom can be taken with respect to the position of developed and developing countries towards such a recognition. To begin with, this duel between the two groups of countries can be observed before and after the efforts of achieving a New International Economic Order (NIEO). Before the NIEO, bilateral treaty practice containing such a standard was favored by developed countries for the fact that there was doubt about the standard of treatment to be accorded to foreign investors. Hence, it is hard to accept that there was consensus between the two groups and likewise FET had passed into customary law. While, after the NIEO, the question is that with the increasing number of FET in BITs, has the FET in recent years become a rule of customary international law? Theoretically, the answer could be in affirmative, however, after all these developments; one can still face with the lack of a clear indication on the part of developing countries to consider themselves obliged as a matter of international law, to offer FET to investors. Likewise, it is argued that for these countries politically as well as economically, it is prudent to provide FET in bilateral arrangements. ${ }^{3}$

One more argument adding to this point is the issue of unequal bargaining power where the content of the modern BITs are largely determined by developed countries and while the developing countries has the option either to accept with limited modification or to reject the treaty in their entirety. However, what about the BITs between developing countries or the countries in transition? For BITs between developing countries at first it can said that these countries might have accepted FET as rule of custom. However, it is posited that it may need some indication from developing countries that the standard has been incorporated not out of convenience or prudence, but because it is required by the prevailing law. As for the countries in transition, even they have entered in numerous BITs embodying the standard, this by itself, does not provide a clear evidence showing their support towards FET as a rule of customary international law. ${ }^{4}$

Finally, the last argument concerns the customary status of FET between developed countries. It is argued that the requirement of state practice and opinio juris might be fulfilled with respect to these countries. For example, the practice of these countries in the form of both multilateral instrument and BITs is unequivocally in favor of the standard. This argument can also be undermined by the fact that the standard would be binding only between two developed countries and it would be unnecessary to determine whether a custom has in fact evolved among developed States as a group. ${ }^{5}$ In summary, the legal doctrine answers this question negatively, arguing that despite FET being present in manifold bilateral and multilateral investment treaties, the subjective element of customary international law namely the opinio juris remains contentious. Therefore, the better view is that FET has not become part of customary international law.

\section{The Arbitral Practice on FET as a Rule of Custom}

Arbitral practice has also embraced the controversial position regarding customary status of FET taken by some arbitral tribunals that has followed with criticism later on by the State Parties, other tribunals and as well as by some writers on this issue. The idea of presence of FET in numerous BITs has also influenced the arbitral practice to rule that FET as such has become part of customary international law. For example, the Pop and Talbot tribunals in its second award of 2002 stated "Canada's view on the appropriate standard of customary international law for today were perhaps shaped by its erroneous belief that only some 70 bilateral investment treaties have been negotiated, however, the true number, now acknowledged by Canada, is in excess of 1800 . Therefore, applying the ordinary rules for determining the content of custom in international law, one must conclude that the practice of states is now represented by those treaties". ${ }^{6}$ Here, for the tribunal the fact that the FET standard was present in the majority of BITs essentially catered the element of State practice needed to prove the existence of a rule of customary international law.

\footnotetext{
${ }^{1}$ See C. Schreuer \& R. Dolzer, Principles of International Investment Law (Oxford UP 2008), p. 124; see also Dumberry (n 7) p. 49

${ }^{2}$ North Sea Continental Shelf Cases (n 8) 44 [77].

${ }^{3}$ Vasciannie (n 6) pp. 157-158

${ }^{4}$ Ibid. at $159-160$

${ }^{5} \mathrm{Ibid}$ at 161-162

${ }^{6}$ Pope \& Talbot Inc. v. Canada, UNCITRAL, Award in Respect of Damages, 31 May 2002. (62).
} 
However, this reasoning is controversial and questionable for different reasons. As discussed in the previous part that for FET to enter as customary rule, it should fulfill the prerequisite of State practice and opinio juris. Even, if there is considerable State practice adopting FET in treaties, this by itself will not indicate that States do so based on a sense of legal obligation. Instead, it is as a means facilitating investment in their respective countries that States conform to do so. Therefore, the tribunal noticeably ignored the requirement to demonstrate opinio juris to establish the existence of a customary rule. Moreover, the tribunal did not point to the actual content of these BITs. ${ }^{1}$ These criticisms were also reflected in $A D F^{2}$ as well as $M o n d e v^{3}$ cases where the tribunals referred to the clear disapproval of the NAFTA parties with the reasoning of the tribunal. ${ }^{4}$

Another tribunal, which seems to have clearly supported the customary status of FET, is the Merrill \& Ring $^{5}$ tribunal. Unlike, Pop and Talbot, this tribunal provided its reason based on the evolution of MST rather than pointing on the inclusion of FET in BITs. In other words, the tribunal simply said that 'against the backdrop of the evolution of the minimum standard of treatment' it was 'satisfied that fair and equitable treatment has become a part of customary law'. ${ }^{6}$ This tribunal however, did not opt to discuss in detail neither State practice nor the opinio juris under the CIL. For further explanation, the tribunal reasoned, "a requirement that aliens be treated fairly and equitably in relation to business, trade, and investment is the outcome of this changing reality and as such it has become sufficiently part of widespread and consistent practice so as to demonstrate that it is reflected today in customary international law as opinio juris. In the end, the name assigned to the standard does not really matter. What matter is that the standard protects against all such acts and or behavior that might infringe a sense of fairness, equity and reasonableness. Of course, the concepts of fairness, equitableness and reasonless cannot be defined precisely: they require to be applied to the facts of each case. In fact, the concept of fair and equitable treatment has emerged to make possible the consideration of inappropriate behavior of a sort, which while difficult to define, may still be regarded as unfair, inequitable or unreasonable". 7

Some tribunals such as Mondev and $\mathrm{Cargill}^{8}$ have taken unclear or cautious approach towards recognition of FET as a rule of custom. First, the Mondev tribunal admitted that 'it is often difficult in international practice to establish at what point obligations accepted in treaties, multilateral or bilateral, come to condition the content of a rule of customary international law binding on States not party to those treaties'. For more clarification, the tribunal at the outset, observed the contention of the US as respondent, which had contended that FET and FPS in NAFTA including other BITs intended to incorporate principles of customary international law. ${ }^{9}$ Then, the tribunal concluded this way, "thus the question is not that of a failure to show opinio juris or to amass sufficient evidence demonstrating it. The question rather is: what is the content of customary international law providing for fair and equitable treatment and full protection and security in investment treaties?"10

The above conclusion of the tribunal is rather unclear and may have two possible interpretations. First, it can mean that the tribunal supported the position hold by the United States that FET refers to the MST found under custom. Second, it may mean that the FET itself has already entered into the corpus of customary international law. Nevertheless, the award contains a few passages that possibly indicate that the tribunal favoured the later position. For example, in one place the tribunal, mentions that the 2000 existing BITs 'almost uniformly' contain an FET clause and points that, 'such a body of concordant practice will necessary have influenced the content of rules governing the treatment of foreign investment in current international law'. ${ }^{11}$ Also, in one more place

\footnotetext{
${ }^{1}$ On this point, see also Dumberry (n 31) p. 54

${ }^{2}$ ADF Group Inc. v. United States, ICSID Case No. ARB (AF)/00/1, Award, 6 January 2003.

${ }_{3}^{3}$ Mondev International Ltd. v. United States, ICSID Case No. ARB (AF)/99/2, Award, 2 October 2012. they include provisions in those treaties such as that for 'fair and equitable' treatment of foreign investment'.

${ }^{5}$ Merrill \& Ring Forestry L.P. v. Canada, UNCITRAL, Award, 31 March 2010.

${ }^{6}$ Ibid. [211]

${ }^{7}$ Ibid. [210]

${ }^{8}$ Cargill, Inc. v. Mexico, ICSID Case No. ARB (AF)/05/02, Award, 18 September 2009.

${ }^{9}$ Mondev (n 41) [111]

${ }^{10}$ Ibid. [113].

${ }^{11}$ Ibid. [117].
}

${ }^{4} A D F$ (n 40) [112]: '[t]he Pope and Talbot Tribunal did not examine the mass of existing BITs to determine whether those treaties represent concordant state practice and whether they constitute evidence of the opinio juris constituent of customary international law.' For the United States, the Pope Tribunal was therefore 'not in a position to state whether any particular BIT obligation has crystallized into a rule of customary international law.' Ibid. [125]; Mondev (n 39) [110]: 'In their post-hearing submissions, all three NAFTA Parties challenged holdings of the Tribunal in Pope \& Talbot which find that the content of contemporary international law reflects the concordant provisions of many hundreds of bilateral investment treaties. In particular, attention was drawn to what those three States saw as a failure of the Pope \& Talbot Tribunal to consider a necessary element of the establishment of a rule of customary international law, namely opinio juris. These States appear to question whether the parties to the very large numbers of bilateral investment treaties have acted out of a sense of legal obligation when 
generally mentioning that the content of "current international law was shaped by the conclusion of more than two thousand bilateral investment treaties and many treaties of friendship and commerce and that those treaties largely and concordantly include an FET clause. ${ }^{1}$ The Chemtura tribunal also agreed a similar position with regard to rule of BITs stating that "the determination of NAFTA Article 1105 cannot overlook the evolution of customary international law, nor the impact of BITs on this evolution". ${ }^{2}$ Therefore, considering the different statements by the tribunal, it can be suggested that the Mondev tribunal actually agreed that the inclusion of FET by States in their BITs in a uniform manner had led to the formulation of a rule of custom. ${ }^{3}$

Coming to Cargill case, the tribunal embraced both possibility and difficulty of FET as norm of customary international law indicating that the FET clause were common in BITs, but also accepted that the actual wording varies. Thus, on one hand the tribunal said that it is "widely accepted that extensive adoption of identical treaty language by many States may in and of itself serve - again with care - as evidence of customary international law'. On the other hand, it suggested that 'significant evidentiary weight should not be afforded to autonomous clauses inasmuch as it could be assumed that such clauses were adopted precisely because they set a standard other than that required by custom. Therefore, the tribunal concluded that it did not believe it prudent to accord significant weight to even widespread adoption of such FET clause. it further pointed that 'it may be that widespread adoption of a strict autonomous meaning to fair and equitable treatment may in time raise international expectations as to what constitute good governance, but such a consequence is different than such clauses evidencing directly an evolution of custom' ${ }^{4}$

Courageously, some tribunals have given FET a customary recognition by supporting the convergence theory. For example, in Occidental, the tribunal opined, 'the treaty standard is not different from that required under international law'. The tribunal also mentioned that 'this means that a minimum fair and equitable treatment must be equated with the treatment required under international law. The reasoning of the tribunal is questionable as it first equates FET with the minimum standard under customary international law and later looks to tribunals applying the additive interpretation of FET to determine the applicable standard. Moreover, this convergence approach leads the tribunals to conclude that as a matter of customary law, states owe duties to foreign corporations the benefits beyond the customary international law and therefore overstates the protections afforded to investors under customary international law. The convergence approach may also cause other governmental actions such as negligence in negotiations, discrimination in the provision of financial assistance, approval of investment that is contrary to government policy and even simple breaches of contract to be in violation of customary international law.

In another side, some tribunals have rejected the idea that FET has itself become part of customary international law. One such example is the $A D F$ tribunal, which took the position saying, "We are not convinced that the Investor has shown the existence, in current customary international law, of a general and autonomous requirement (autonomous, that is from specific rules addressing particular, limited, contexts) to accord fair and equitable treatment and full protection and security to foreign investments. The investor, for instance, has not shown that such a requirement has been brought into the corpus of present day customary international law by the many hundreds of bilateral investment treaties now extant. It may be that, in their current state, neither concordant state practice nor judicial or arbitral case law provides convincing substantiation (or, for that matter, refutation) of the investor's position". ${ }^{5}$ Here, the tribunal expressly refuted the claim made by the investor that FET had become part of customary law. The tribunal also had stated that the Mondev ruling was just 'implying that the process was in motion, and that tribunal had not backed that FET was in fact a customary rule. ${ }^{6}$ Similarly, the tribunal in Glamis Gold v. United States rejected the claimant's argument that 'BIT jurisprudence on the FET has converged with customary international law in this area' and found this as an 'overstatement'.

In short, only a few tribunals such as Pop \& Talbot, and Merrill \& Ring have expressly agreed with the customary status of FET. Other tribunals such as Mondev and Chemtura though not clearly also seems to have adopted such a position. On the other side, tribunals for instance ADF and Glamis Gold tribunals have rejected

\footnotetext{
${ }^{1}$ Ibid. [125].

${ }^{2}$ Chemtura Corporation v. Canada, UNCITRAL, Award, 2 August 2010 [121].

${ }^{3}$ Alexander Orakhelashvili, "The Normative Basis of "Fair and Equitable Treatment": General International Law on Foreign Investment?' (2008) 1 Archive des Völkerrechts, p. 78; Laird (n 27) pp. 70-7467, 69, 70. See also Stephan W. Schill, 'Fair and Equitable Treatment, the Rule of Law, and Comparative Public Law' in Stephan W. Schill (ed) International Investment Law and Comparative Public Law (Oxford UP 2010) p. 153.

${ }^{4}$ Cargill (n 46) [276]

${ }^{5} \mathrm{ADF}(\mathrm{n} 40)$ [183], [185].

${ }^{6}$ Ibid. [183]

${ }^{7}$ Glamis Gold Ltd v. United States, UNCITRAL, Award, 14 May 2009 [609].
} 
such a recognition. As can be observed, the tribunals supporting this status mostly based their reasoning on the existence of FET in the overwhelming majority of BITs or the evolution of custom represented in the modern formulation of FET. However, the reasoning of these tribunals arguing that the multiplicity of treaty instruments on the given subject can produce the customary law regulation on the same subject is defective, as they have not properly embarked on the double requirement of State practice and opinio juris. An ICJ rule in the case of Ahmadou Sadio Diallo, which dealt with the issue of diplomatic protection, supports such an argument. The court received the argument that the regulation of diplomatic protection in treaty regimes had caused the change in customary law on this subject, and thereby the State of the nationality of the company's shareholders could exercise the diplomatic protection for the breaches of the rights of the company by substitution. The court did not accept to see the modification of customary international law in this way. In other words, for the court, the adjustment of the subject matter in treaty regimes was not enough as evidence. ${ }^{1}$

At the end, something should be said about the overall role of arbitral decisions themselves with regard to recognition of a standard as rule of custom. In this matter, for example, the NAFTA governments have repeatedly insisted that the decisions of arbitral tribunals are not themselves a source of customary international law. Thus, ISDS awards that merely set forth arbitral views about customary international law are not relevant. ${ }^{2}$ For example, Canada during the Chemtura case in its counter - Memorial citing Sir Hersch Lauterpacht noted, "Decisions of international courts are not a source of international law. They are not direct evidence of the practice of States or of what States conceive to be the law. Arbitral decisions are relevant to the determinations of custom only to the extent that they contain valuable analysis of State practice. They may provide a useful tool for determining the content of customary international law in this way. They do not in themselves constitute the practice of States". For Canada, the cases cited by the Claimant, do not contain an analysis of either State practice or opinio juris. ${ }^{3}$

\section{The Findings through State Practice and Opinio Juris}

For FET to be truly recognized as a rule of custom, it should fulfill the requirement of State practice and opinio juris. In other words, on the one hand, it needs to be shown that a significant number of States have entered into numerous BITs that contain the standard similarly drafted. On the other hand, they have to show there is opinio juris among these countries. These two requirements also known as 'double requirement' or the 'traditional approach'4 is the base of overall determination of any rule of customary international law as well. As the ICJ provided that to establish a rule of customary international law, it is "an indispensable requirement to demonstrate that State practice, including that of States whose interests are specially affected, should have been both extensive and virtually uniform in the sense of the provision invoked. And should moreover have occurred in such a way as to show a general recognition that a rule of law or obligation is involved". 5 In practice, as the ILC Special Rapporteur Wood explained the above-mentioned double requirement is 'generally adopted in the practice of States and the decisions of international courts and tribunals, including the ICJ and it is widely endorsed in the literature'. ${ }^{6}$

This double requirement both must be shown for a well-established rule of customary international law. On the one hand, State practice is crucial, as custom cannot be established only through opinio juris ${ }^{7}$ and hence deriving custom 'purely from opinio juris can create utopian laws that cannot regulate reality'. ${ }^{8}$ In other words, opinio juris absent of State practice is 'nothing more than rhetoric'. ${ }^{9}$ On the other hand, the existence of opinio juris is important to distinguish between real international obligations and mere non-legal motivations ${ }^{10}$ such as

\footnotetext{
${ }^{1}$ Ahmadou Sadio Diallo, Preliminary Objections, General List No 103, Judgment of 24 May 2007, paras 88-90.

${ }^{2}$ See Mesa, Mexico Second Non-Disputing Party Submission, para. 10 ("Mexico concurs with Canada's submission that decisions of arbitral tribunals are not themselves a source of customary international law ...."). Also, Mesa, Canada Response to Non-Disputing Party Submissions, para. 11 ("Canada has explained at length in its pleadings as to why decisions of international investments tribunals are not a source of State practice for the purpose of establishing a new customary norm."). ${ }^{3}$ Chemtura, Canada Rejoinder, para. 167.

${ }^{4}$ See A.E. Roberts, 'Traditional and Modern Approaches to Customary International Law: A Reconciliation', (2001) 95 AJIL, 758 , notably described this approach as one 'focusing primarily on state practice in the form of interstate interaction and acquiescence', with opinio juris being 'a secondary consideration invoked to distinguish between legal and nonlegal obligations'.

${ }^{5}$ North Sea Continental Shelf Cases (n 8) 43 [74].

${ }^{6}$ International Law Commission, 'Second Report on Identification of Customary International Law', by Michael Wood, Special

Rapporteur, Sixty-sixth session, Geneva, 5 May-6 June and 7 July-8 August 2014, UN Doc. A/CN.4/672, p. 8

${ }^{7}$ Villiger (n 8), p. 288; H.W.A. Thirlway, International Customary Law and Codification (Sijthoff 1972), p. 56.

${ }^{8}$ Roberts (n 60), p. 757

${ }^{9}$ Y. Dinstein, 'The Interaction between Customary International Law and Treaties', (2006) 322 Rec. des cours, 294.

${ }^{10}$ Villiger (n 8), p. 48.
} 
'courtesy, political expediency, will or compromise, precautionary measures, expressions of intent and aspirations or preferences. ${ }^{1}$ Moreover, opinio juris is essential to show how the accumulation of uniform and consistent State practice can transform into a legal rule binding on all States. ${ }^{2}$ As pointed by the ICJ in the North Sea Continental Shelf cases, 'acting, or agreeing to act in a certain way, does not itself demonstrate anything of a juridical nature.' 3 Therefore, it is necessary to prove that something that States typically and often do transforms to something that they feel they have to do it under international law. ${ }^{4}$ In this respect, Dinstein succinctly stated that opinio juris 'underpins the transition of State practice from the normal to the normative'. ${ }^{5}$ Overall, in the words of Kammerhofer, 'the reason why both elements can be seen to be necessary is that without usus it would not be customary and without opinio it would not be law. ${ }^{6}$

To begin with, the State practice first must be general ${ }^{7}$ and or according to ICJ, "widespread" ${ }^{8}$ and 'sufficiently extensive and convincing'. ${ }^{9}$ It means this requirement is relative and there is no need for a particular number or percentage of States to show general practice. ${ }^{10}$ However, it cannot be left in abstract, what indeed matters is the degree of representativeness of the States actively engaged in that practice. ${ }^{11}$ In a recent study made by Dumberry, from a collection of 2000 BITs, only 50 did not include FET while 25 others had FET in their preambles. While only less than 5 percent of all BITs in his study did not cover FET. ${ }^{12}$ Even here, no country has systematically excluded FET clauses from its treaties while the few states which have done it, it has been only with their minority of BITs. For example, the States in Eastern Europe particularly have adopted BITs with no FET clauses. On the other side, such kind of clause excluding FET are not common in practice of developing countries. Therefore, this requirement of States practice seems to be fulfilled. ${ }^{13}$

The second requirement is that State practice must be representative. The ICJ in the North Sea Continental cases mentions the condition of 'very widespread and representative participation' in the formation of a rule. ${ }^{14}$ In addition, ILA final report clarifies that 'it is not simply a question of how many States participate in the practice, but which States. ${ }^{15}$ As, in the early stages of the development of FET, the standard was supported by developed countries and developing countries embraced the standard by the passage of time particularly after $1990 \mathrm{~s}$, as well. ${ }^{16}$ Now, the FET is included in multilateral instruments such as Energy Charter Treaty (ECT) $)^{17}$ in Europe, NAFTA ${ }^{18}$ in North America, Latin America ${ }^{19}$, Asia ${ }^{20}$ and Africa. ${ }^{21}$ The standard is also embodied the BITs of developing countries as such in model BITS of both developed and developing countries. ${ }^{22}$ Taken the considerable presence

\footnotetext{
${ }^{1}$ International Law Commission, 'Formation and Evidence of Customary International Law, Elements in the Previous Work of the ILC that Could be Particularly Relevant to the Topic', Memorandum by the Secretariat, Sixty-fifth session Geneva, 5 May7 June and 8 July-9 August 2013, UN Doc., A/CN.4/659 [19].

2 Karol Wolfke, Custom in Present International Law (2nd ed., Nijhoff 1993, p. 44.

${ }^{3}$ North Sea Continental Shelf Cases (n 8) 44 [76].

${ }^{4}$ International Law Commission, 'Third Report on Identification of Customary International Law', by Michael Wood, Special Rapporteur, Sixty-seventh session, Geneva, 4 May-5 June and 6 July-7 August 2014, A/CN.4/682 [6].

${ }^{5}$ Dinstein (n 65), p. 294.

${ }^{6}$ Jörg Kammerhofer, 'Customary International Law Needs both Opinio and Usus', paper presented at the conference 'The Role of Opinio Juris in Customary International Law', Duke-Geneva Institute in Transnational Law, Geneva, 2013, p. 2

${ }^{7}$ ILC Memorandum (n 67) 10-11 (noting the different expressions used by the ILC); ILC Second Report (n 62) 34.

${ }^{8}$ Maritime Delimitation and Territorial Questions between Qatar and Bahrain, Merits, Judgment, ICJ Rep. 2001, 40 [205].

${ }^{9}$ Delimitation of the Maritime Boundary in the Gulf of Maine Area (Canada/United States), Judgment, ICJ Rep. 1984, 299 [111].

${ }^{10}$ Maurice H. Mendelson, ‘The Formation of Customary International Law' (1985) 192 Rec. des cours, p. 219-224.

${ }^{11}$ International Law Association, 'Statement of Principles Applicable to the Formation of General Customary International Law', Final Report of the Committee on the Formation of Customary Law, Conference Report London (2000) 17 [25, 26]; ILC Second Report (n 62) [34].

${ }^{12}$ See Dumberry (n 7), p. 66

${ }^{13}$ Ibid. at p. 68

${ }^{14}$ North Sea Continental Shelf Cases (n 8) [73]

${ }^{15}$ ILA Final Report (n 77) [25].

${ }^{16}$ See Schreuer \& Dolzer (n 33), p. 16; Stephen Schwebel, 'The United States 2004 Model Bilateral Investment Treaty: An Exercise in the Regressive Development of International Law', in Global Reflections on International Law, Commerce and Dispute Resolution, Liber Amicorum in honour of Robert Briner (No. 693, ICC Pub. 2005) 647. p. 28. See also, for instance: OECD, International Investment Law: A Changing Landscape, A Companion Volume to International Investment Perspectives (2005) [78].

${ }^{17}$ Energy Charter Treaty Art. 10 (1).

${ }^{18}$ NAFTA (n 21) Art. 1105.

${ }^{19}$ Art. 2, Colonia Protocol in the context of Mercosur.

${ }^{20}$ ASEAN Treaty for the Promotion and Protection of Investments (Article IV).

${ }^{21}$ Common Market for Eastern and Southern Africa (COMESA) (Article 159(1) (a).

${ }^{22}$ Vasciannie (n 6) pp. 129-130.
} 
of FET in various multilateral instruments and BITS across the regions of the world, it can said that the practice of State to contain FET in their BITs is representative.

The third requirement is uniformity and consistency of State practice, which has also been endorsed by several ICJ cases. ${ }^{1}$ Unlike the other two above-mentioned requirements, this is a controversial one as some writers and scholars have conflicting opinions towards such a reality. This controversy is mainly related to different language and wording of FET in BITs. For example, for Tudor, FET's language differences 'refer to the level of the treatment to be accorded to the Investors, not to the standard within its content.' ${ }^{2}$ Similarly, Diehl believes that these drafting differences 'do not touch upon the core of the FET standard. ${ }^{3}$ In the opposite side, many scholars believe that how can one truly speak of uniformity when there exist five or six different FET models. ${ }^{4}$ As, there are two prominent formulation of FET the one being linked with international and the other the unqualified or autonomous FET. Therefore, these clauses can hold different meaning and further impact the liability threshold when arbitral tribunals interpret them. ${ }^{5}$ Furthermore, the ILA noted that 'if there is too much inconsistency between States in their practice, there is no general custom and hence no general customary international law' ${ }^{6}$ In addition, it discussed over virtual uniformity ${ }^{7}$ both internally and collectively. ${ }^{8}$ As for collective uniformity, 'different States must not have engaged in substantially different conduct, some doing one thing and some another. ${ }^{9}$ For all these reasons and in conformity with Dumberry's findings on this issue, it can concluded that FET is not uniform within the practice of States in the context of BITs. ${ }^{10}$

Apart from State's practice in their treaties, it is also important to discover the practice of States outside the treaty framework. Here, also, it must be shown that States are providing FET uniformly and consistently in their own practice outside the treaties. This may include a situation where States are not party to any BIT or States are parties to BITs not containing the standard. The domestic laws would be a clear example of such a situation. It has been suggested by some writers that FET is found in the domestic laws of most developed and developing States. ${ }^{11}$ However, some other writers have disapproved this argument. For example, Vasciannie's study on the domestic legislations of a number of capital importing States shows that the 'overwhelming majority' of these States do not provide FET protection to foreign investors. ${ }^{12}$ Likewise, Parra's study of national legislations in 51 developing countries, found that only three of them contained FET standard. ${ }^{13}$ Moreover, according to Dumberry's examination of 165 foreign investment laws from 160 States, 10 expressly has referred to the standard. ${ }^{14}$ In short, only the investment laws of a small number of States have provide for FET. However, against this background, one should not conclude that FET is absent in these States. FET may exist, for example, within these State's constitution. In an opposite situation, the fact that FET exist in a State's legislation is no guarantee that investors for sure will obtain the FET protection. ${ }^{15}$

\footnotetext{
${ }^{1}$ Colombian-Peruvian Asylum Case, Judgment, ICJ Rep. 1950. 276; Military and Paramilitary Activities in and around Nicaragua, (Nicaragua v. United States) Merits, Judgment, ICJ Rep. 1986, [186]; Fisheries Jurisdiction Case (n 14) [50].

${ }^{2}$ Tudor (n 27), p. 77

${ }^{3}$ Diehl (n 27), pp. 134-5.

${ }^{4}$ Andrew Newcombe \& Luis Paradell, Law and Practice of Investment Treaties: Standards of Treatment (Kluwer 2009), p. 271, fn 188; Marcela Klein Bronfman, 'Fair and Equitable Treatment: An Evolving Standard' (2006) 10 Max Planck Yrbk. UNL p. 656; Tarcisio Gazzini, 'The Role of Customary International Law in the Field of Foreign Investment' (2007) 8 J. World Invest. \& Trade 698; Abdullah Al Faruque, 'Creating Customary International Law Through Bilateral Investment Treaties: A Critical Appraisal' (2004) 44 Indian JIL, p. 304; Cai Congyan, 'International Investment Treaties and the Formation, Application and Transformation of Customary International Law Rules', (2008) 7 Chinese JIL, pp. 664, 667; Orakhelashvili (n 52 ) p. 77.

${ }^{5}$ See also Patrick Dumberry, The Fair and Equitable Treatment Standard: A Guide to NAFTA Case Law on Article 1105 (Wolters Kluwer 2013). 40ff.

${ }^{6}$ ILA Final Report (n 77) [22].

${ }^{7}$ North Sea Continental Shelf Cases (n 8) [74].

${ }^{8}$ ILA Final Report (n 77) [21].

${ }^{9}$ Ibid.

${ }^{10}$ See Dumberry (n 7), p. 71.

${ }^{11}$ For example, Tudor (n 27), p. 104 (In the case of the FET standard, the situation as it stands today is that most developed and developing countries do recognize in their domestic laws that FET is to be applied to foreign investors. This is the case even though the term FET itself may not be employed as such but the content of FET, namely procedural and substantive guarantees for foreign investors, is found in national provisions'); Diehl (n 27), p. 174.

${ }^{12}$ Vasciannie (n 6) 160.

${ }^{13}$ A. Parra, 'Principles Governing Foreign Investment, as Reflected in National Investment Codes' (1992) 7 ICSID Rev. 435 7.

${ }^{14}$ Patrick Dumberry, 'The Practice of States as Evidence of Custom: Fair and Equitable Treatment Standard Clauses in States' Foreign Investment Laws', (2015-16) 2 McGill JDR pp. 66-81.

${ }^{15}$ See also Dumberry (n 7), p. 74
} 
Another example could be the State's contract with the companies and individuals encompassing such a standard. Again, according to Dumberry's above-mentioned study, there exist no any such contract to refer to such standard. ${ }^{1}$ However, it is doubtful with regard to confidential State contracts to be considered as a relevant evidence of State practice because of the publicity requirement towards the formulation of custom. ${ }^{2}$ Furthermore, there seems to be no arbitration award mentioning FET in States contract or the investor's claim alleging the presence of FET in such a contracted to eventually be respected by the host states. More generally, in the absence of BIT or BIT containing no FET, there is no arbitration case requiring States to provide such a protection. ${ }^{3}$ Thus, based on the findings both through investment laws of States as well as States contracts with investors, there is no indication to conclude that States outside the treaty as well provide a uniform and consistent protection of FET to investors.

Finally, the second general component of a customary international law is opinio juris. Same with the State practice, some writers as mentioned earlier have argued that the presence of FET in a great number of BITs is representative of the opinio juris of States as well. ${ }^{4}$ However, as stated by the ILC Special Rapporteur Wood, 'when the parties to a treaty act in fulfilment of their conventional obligations, this does not generally demonstrate the existence of an opinio juris. ${ }^{5}$ Likewise, as explained by Schechter, 'the repetition of common clauses in bilateral treaties does not create or support an influence that those clauses express customary law because to sustain such a claim of custom one would have to show that apart from the treaty itself, the rules in the clauses are considered obligatory'. ${ }^{6}$ Therefore, States simply performing their conventional duty has nothing to do with custom.

Furthermore, looking for the historical disagreement between the developed and developing countries on the issue of MST and accepting FET afterwards as a conventional standard, it is difficult to accept the proposition of FET included in BITs as a norm of custom. As Vasciannie rightly argued that, "it would be difficult to posit that there was consensus between developed and developing countries that the FET standard had passed into customary law'. He further pointed that 'one would be hard-pressed to identify supportive opinio juris, particularly on the part of developing States'. 'Apart from this argument, there seems to be no indication both in treaty text or travaux preparatoires to show that States has a sense obligation to Provide FET to foreign investors. ${ }^{8}$ However, it should not be understood that a BIT might not contain clauses that States have opinio juris towards them at all. In this respect, Dumberry's study found that there were some examples of such an opinio juris, though in other contexts in BITs but not with regard to FET. ${ }^{9}$

Based on these findings, a number of observations can be made with respect to existence of State practice and opinio juris towards FET in the context of BITs. First, for State practice, the entire requirement of it as enshrined by the ICJ is not fulfilled. To put it the other way, the State practice is general and widespread as well as representative, however, it is not uniform and consistent. Moreover, the practice of States outside the treaty framework, as was observed in the States' legislation and States' contracts with investors, indicates that there is no uniform and consistent FET protection within them. As for the opinio juris, it was found that States simply fulfilling their obligations has nothing to do with custom. In addition, there is nothing in the treaty text, preparatory works or anywhere else to demonstrate that States provide FET out of a sense of obligation towards foreign investors, let alone the historical controversy over such a recognition. Therefore, it can be concluded here that except generality and representativeness of State practice, generally there is no support of uniform and consistent State practice within BITs or outside treaty framework as well as opinio juris to argue that, FET has become a rule of customary international law.

\section{Conclusion}

The quest of this paper was to find the answer for the controversial question of whether FET has itself become part of customary international law or not. The answer to this question is important because if the standard has, in fact, become a part of customary international law, then even where States exclude reference to FET for foreign investors in their treaty arrangements, this level of treatment will come into effect by operation of law to such

\footnotetext{
${ }^{1}$ Patrick Dumberry (n 102), p. 66-81

${ }^{2}$ See ibid; see also P. Dumberry, The Formation and Identification of Rules of Customary International Law in International Investment Law (Cambridge UP 2016), p. 152.

${ }^{3}$ Ibid.

${ }^{4}$ See p. 3 , fn 25

${ }^{5}$ ILC Second Report (n 62) 43

${ }^{6}$ Oscar Schechter, 'Compensation for Expropriation' (1986) 78 AJIL 126.

${ }^{7}$ Vasciannie (n 6) pp. 157-158.

${ }^{8}$ Dumberry (n 7), p. 75

${ }^{9}$ Dumberry (n 105) 325ff.
} 
investors. While if it has not become, the courts would not be able to bring it into play unless it was formally contained in investment treaties.

For this purpose, the paper first went through the conflicting arguments among scholars to find the answer. According to some scholars such as Schwebel, FA Mann, Tudor, Diehl, FET has itself entered into the corpus of customary international law. The main reason for them has been the inclusion of FET in majority of international investment agreements. However, in the other side, majority of scholars such as Vasciannie, Schwebel, Schreuer Weiler and Dumberry opposed such a recognition. Their main reason is that there is lack of consistency and uniformity of FET practice by States as well as the absence of opinio juris. Furthermore, if FET exited under custom, States would not need to include such a protection in their BITs. In short, the legal doctrine answers this question negatively, arguing that despite FET being present in manifold bilateral and multilateral investment treaties, the subjective element of customary international law namely the opinio juris remains contentious.

Secondly, the paper analyzed a number of arbitral cases dealing with the question of customary status of FET. As observed, only a few cases such as Pop \& Talbot, and Merrill \& Ring have expressly agreed with the customary status of FET. Other tribunals such as Mondev and Chemtura though not clearly also seems to have adopted such a position. On the other side, tribunals for instance ADF and Glamis Gold tribunals have rejected such a recognition. In fact, the tribunals supporting this status mostly based their reasoning on the existence of FET in the overwhelming majority of BITs or the evolution of custom represented in the modern formulation of FET.

Lastly, the paper scrutinized the two requirements for the formulation of a customary international law namely State practice and opinio juris with respect to FET standard. Here also, the entire necessary elements of it as enshrined by the ICJ is not fulfilled. In other words, except generality and representativeness of State practice, generally there is no support of uniform and consistent State practice within BITs or outside treaty framework as well as opinio juris to argue that, FET has become a rule of customary international law. Therefore, the answer to the question raised at the beginning is no as FET itself has not become a customary standard.

\section{References}

Abdullah Al Faruque, 'Creating Customary International Law Through Bilateral Investment Treaties: A Critical Appraisal' (2004) 44 Indian JIL.

ADF Group Inc. v. United States, ICSID Case No. ARB (AF)/00/1, Award, 6 January 2003.

A.E. Roberts, 'Traditional and Modern Approaches to Customary International Law: A Reconciliation', (2001) 95 AJIL.

Ahmadou Sadio Diallo, Preliminary Objections, General List No 103, Judgment of 24 May 2007, paras 88-90.

Alfred Siwy, 'Investment Arbitration - Indirect Expropriation and the Legitimate Expectations of the Investor' in Christian Klausegger et al. (eds), Austrian Arbitration Yearbook 2007 (C.H. Beck, Stämpfli and Manz 2007).

Alexandra Diehl, The Core Standard of International Investment Protection: Fair and Equitable Treatment (Wolters Kluwer 2012).

Alexander Orakhelashvili, 'The Normative Basis of "Fair and Equitable Treatment": General International Law on Foreign Investment?’ (2008) 1 Archive des Völkerrechts.

Havana Charter for the Establishment of an International Trade Organization ('Havana Charter') (signed 24 March 1948).

Andrew Newcombe \& Luis Paradell, Law and Practice of Investment Treaties: Standards of Treatment (Kluwer 2009).

ASEAN Agreement for the Promotion and Protection of Investments (signed 15 December 1987).

A. Parra, 'Principles Governing Foreign Investment, as Reflected in National Investment Codes' (1992) 7 ICSID Rev.

Cai Congyan, 'International Investment Treaties and the Formation, Application and Transformation of Customary International Law Rules', (2008) 7 Chinese JIL. 
Cargill, Inc. v. Mexico, ICSID Case No. ARB (AF)/05/02, Award, 18 September 2009.

Chemtura Corporation v. Canada, UNCITRAL, Award, 2 August 2010 [121].

Colombian-Peruvian Asylum Case, Judgment, ICJ Rep. 1950.

Courtney C. Kirkman, 'Fair and Equitable Treatment: Methanex v. United States and the Narrowing Scope of NAFTA Article 1105', (2002-2003) 34 Law \& Pol'y Int'l Bus.

C. Schreuer \& R. Dolzer, Principles of International Investment Law (Oxford UP 2008).

Delimitation of the Maritime Boundary in the Gulf of Maine Area (Canada/United States), Judgment, ICJ Rep. 1984, 299.

Deng, Tingting. "The impact of the fair and equitable treatment standard on state sovereignty: from the perspective of international investment practice." PhD diss., City University of Hong Kong, 2012.

Dumberry P (2017) Fair and Equitable Treatment: Its Interaction with the Minimum Standard and its Customary Status (Brill Research Perspectives in International Investment Law and Arbitration).

Energy Charter Treaty (signed 17 December 1994, entered into force 16 April 1998); 2080 UNTS 95; ILM 34 (1995).

FA Mann, British Treaties for the Promotion and Protection of Investments, 5 BYIL (1982).

Glamis Gold Ltd v. United States, UNCITRAL, Award, 14 May 2009.

Government of Canada, Response to 1128 Submissions, 26 June 2015, in Mesa Power Group LLC v. Government of Canada, PCA Case No. 2012-17.

Havana Charter for the Establishment of an International Trade Organization ('Havana Charter') (signed 24 March 1948).

H.W.A. Thirlway, International Customary Law and Codification (Sijthoff 1972) 56.

I. Laird, 'Betrayal, Shock and Outrage - Recent Developments in NAFTA Article 1105', in T. Weiler (ed.), NAFTA Investment Law and Arbitration: Past Issues, Current Practice, Future Prospects (Transnational Publ., 2004).

International Law Association, 'Statement of Principles Applicable to the Formation of General Customary International Law', Final Report of the Committee on the Formation of Customary Law, Conference Report London (2000) 17.

International Law Commission, 'Second Report on Identification of Customary International Law', by Michael Wood, Special Rapporteur, Sixty-sixth session, Geneva, 5 May-6 June and 7 July-8 August 2014, UN Doc. A/CN.4/672.

International Law Commission, 'Third Report on Identification of Customary International Law', by Michael Wood, Special Rapporteur, Sixty-seventh session, Geneva, 4 May-5 June and 6 July-7 August 2014, A/CN.4/682.

International Trade Organization, The Havana Charter (1948).

Ioana Tudor, The Fair and Equitable Treatment Standard in International Foreign Investment Law (Oxford UP 2008).

Jörg Kammerhofer, 'Customary International Law Needs both Opinio and Usus', paper presented at the conference 'The Role of Opinio Juris in Customary International Law', Duke-Geneva Institute in Transnational Law, Geneva, 2013.

Karol Wolfke, Custom in Present International Law (2nd ed., Nijhoff 1993).

Mark E. Villiger, Customary International law and Treaties: A Manual on the Theory and Practice of the Interrelation of Sources (2nd edn., Kluwer 1997).

Maurice H. Mendelson, ‘The Formation of Customary International Law’ (1985) 192 Rec. des cours. 
Marcela Klein Bronfman, 'Fair and Equitable Treatment: An Evolving Standard' (2006) 10 Max Planck Yrbk. UNL.

Maritime Delimitation and Territorial Questions between Qatar and Bahrain, Merits, Judgment, ICJ Rep. 2001, 40 .

Memorandum by the Secretariat, Sixty-fifth session Geneva, 5 May-7 June and 8 July-9 August 2013, UN Doc., A/CN.4/659.

Merrill \& Ring Forestry L.P. v. Canada, UNCITRAL, Award, 31 March 2010.

Military and Paramilitary Activities in and around Nicaragua, (Nicaragua v. United States) Merits, Judgment, ICJ Rep. 1986.

Mondev International Ltd. v. United States, ICSID Case No. ARB (AF)/99/2, Award, 2 October 2012.

North American Free Trade Agreement ('NAFTA') (signed 17 December 1992, entered into force 1 January 1994).

North Sea Continental Shelf Cases (Federal Republic of Germany v. Denmark / Federal Republic of Germany v. Netherlands), [1969] ICJ Rep 42.

OECD, Draft Convention on the Protection of Foreign Property (1967).

OECD, International Investment Law: A Changing Landscape, A Companion Volume to International Investment Perspectives (2005).

OECD Multilateral Agreement on Investment ('MAI') (draft-consolidated text of 22 April 1998).

Oscar Schachter, 'Compensation for Expropriation’ (1986) 78 AJIL.

Patrick Dumberry, The Fair and Equitable Treatment Standard: A Guide to NAFTA Case Law on Article 1105 (Wolters Kluwer 2013).

P. Dumberry, The Formation and Identification of Rules of Customary International Law in International Investment Law (Cambridge UP 2016).

Patrick Dumberry, 'The Practice of States as Evidence of Custom: Fair and Equitable Treatment Standard Clauses in States' Foreign Investment Laws', (2015-16) 2 McGill JDR.

Pope \& Talbot Inc. v. Canada, UNCITRAL, Award in Respect of Damages, 31 May 2002.

Protocol of Colonia for the Promotion and Reciprocal Protection of Investments in MERCOSUR ('MERCOSUR Colonia Protocol') (signed 17 January 1994).

Rejoinder Memorial, 10 July 2009, in Crompton (Chemtura) Corp. v. Government of Canada.

Schwebel, The Influence of Bilateral Investment Treaties on Customary International Law. 98 ASIL Proceedings (2004), 27.

Second Submission of Mexico Pursuant to NAFTA article 1128, in Mesa Power Group LLC v. Government of Canada, PCA Case No. 2012-17.

Stephen Schwebel, 'The United States 2004 Model Bilateral Investment Treaty: An Exercise in the Regressive Development of International Law', in Global Reflections on International Law, Commerce and Dispute Resolution, Liber Amicorum in honour of Robert Briner (No. 693, ICC Pub. 2005) 647.

Stephan W. Schill, 'Fair and Equitable Treatment, the Rule of Law, and Comparative Public Law' in Stephan W. Schill (ed) International Investment Law and Comparative Public Law (Oxford UP 2010).

S. Vasciannie, 'The Fair and Equitable Treatment Standard in International Investment Law and Practice', BYIL 70 (1999).

Tarcisio Gazzini, 'The Role of Customary International Law in the Field of Foreign Investment' (2007) 8 J. World Invest. \& Trade.

The Abs-Shawcross Draft Convention on Investment Abroad (1957). 
Todd Weiler, 'NAFTA Investment Arbitration and the Growth of International Economic Law', (2002) 2 Bus. L. Int'l.

Treaty establishing the Common Market for Eastern and Southern Africa ('COMESA') (signed 5 November 1993, entered into force 8 December 1994); 2314 UNTS 265; ILM 33 (1994).

UNCTAD, International Investment Instruments: A Compendium (1996), vol. I.

World Bank Guidelines on the Treatment of Foreign Direct Investment ('World Bank Guidelines 1992).

Y. Dinstein, ‘The Interaction between Customary International Law and Treaties', (2006) 322 Rec. des cours. 